\title{
EXPERIMENTAL FISHING BUBU LIPAT MODIFIKASI KONSTRUKSI DUA PINTU UNTUK PENANGKAPAN RAJUNGAN (Portunus spp)
}

\section{Experimental Fishing of Two Entrances on the Funnel Construction of Modified Collapsible Pot for Catching Blue Swimming Crab (Portunus spp)}

Oleh:

\author{
Wilda Dwi Utami ${ }^{1}$, Zulkarnain ${ }^{1 *}$, Sulaeman Martasuganda ${ }^{1}$, Vita Rumanti \\ Kurniawati ${ }^{1}$ \\ ${ }^{1}$ Departemen Pemanfaatan Sumberdaya Perikanan, FPIK-IPB, Bogor \\ *Korespondensi penulis: zulkarnain@apps.ipb.ac.id
}

\begin{abstract}
ABSTRAK
Bubu sebagai alat tangkap perangkap pasif yang bersifat menjebak bagi ikan dan hasil tangkapan lainnya. Konstruksi bubu yang digunakan nelayan masih bisa dikembangkan untuk meningkatkan nilai produktivitas hasil tangkapan. Penelitian ini bertujuan untuk melakukan uji coba penangkapan dengan bubu lipat penelitian, menentukan komposisi, membandingkan dan menghitung produktivitas bubu lipat penelitian. Metode yang digunakan mulai dari mendesain, membuat konstruksi dan jumlah ulangan dalam uji coba alat sebanyak 20 trip. Analisis yang digunakan yaitu analisis deskriptif, uji Wilcoxon, Uji T dan rumus produktivitas. Hasil penelitian menunjukkan bahwa ukuran bubu lipat modifikasi dua pintu lebih besar. Komposisi hasil tangkapan pada bubu lipat modifikasi dua pintu 54,89 kg dengan 11 jenis ikan lebih tinggi dibandingkan komposisi pada bubu lipat nelayan (kontrol) 47,44 $\mathrm{kg}$ dengan 9 jenis ikan. Hasil tangkapan rajungan tidak berbeda nyata baik dalam berat $(\mathrm{kg})$ maupun jumlah ikan (ekor) $(\mathrm{P}<0,05)$, untuk hasil tangkapan bernilai ekonomis berbeda nyata baik dalam berat $(\mathrm{kg})$ maupun jumlah (ekor) pada bubu lipat kontrol dan pada bubu lipat modifikasi dua pintu $(\mathrm{P}<0,05)$ sedangkan nilai produktivitas total pada bubu lipat kontrol lebih kecil dibandingkan bubu lipat modifikasi dua pintu.
\end{abstract}

Kata kunci: bubu lipat, modifikasi, rajungan, produktivitas

\begin{abstract}
Fish trap as passive catching device that catch fishes and other biota. Fish trap construction used by fishermen can still be improved in order to increase productivity value of the catch. Objective of this research are conducting experimental fishing of modified collapsible pot with two entrance, determining composition, comparing and calculating productivity value of catch of collapsible pot modification with control. Method used in this research has these following steps; designing, constructing, and experimental fishing for 20 fishing trips. In analyzing the result, this research used descriptive analysis, Wilcoxon test, T test and productivity formula. Results shows that the size of collapsible pot modification two-entrance is bigger. The catch on the collapsible pot two-entrance weight $54.89 \mathrm{~kg}$ with 11 types of fish, higher than the composition in the fishermen's collapsible pot (control) with $25.63 \mathrm{~kg}$ and 11 types of fish. The result showed in the crab catch there was no difference both in weight ( $\mathrm{kg}$ ) and number of catch (fish individu) ( $P<0.05)$, for economical catches a significant difference was found both in weight $(\mathrm{kg})$ and number (individual of fish) on the control and modified two-entrance collapsible pot $(P<0.05)$. In addition, total productivity value on control collapsible pot was smaller than the value on the two-entrance collapsible pot modification.
\end{abstract}

Key words: collapsible pot, modification, blue swimming crab, productivity 


\section{PENDAHULUAN}

Bubu merupakan alat tangkap perangkap yang bersifat pasif (Thomas 1973, Subani dan Barus 1989, Martasuganda 2003, Hatapayo 2004, Baskoro dan Effendy 2005, Zulkarnain 2012, Iskandar dan Rachmad 2013, Purwanto et al. 2013) yang merupakan jebakan bagi ikan dan hasil tangkapan lainnya (Purwanto et al. 2013). Menurut Baskoro (2006) perangkap adalah salah satu alat penangkap yang bersifat statis yang umumnya berbentuk kurungan, berupa jebakan dimana ikan akan mudah masuk tanpa adanya paksaan dan sulit untuk keluar atau lolos karena dihalangi oleh berbagai cara. Menurut Krouse (1989), efektivitas bubu pada umumnya dipengaruhi oleh umpan, keberadaan biota, tingkah laku biota, metode pengoperasian alat dan bentuk konstruksi. Namun, konstruksi bubu yang digunakan nelayan masih bisa dikembangkan melalui kajian ilmiah terhadap bubu tersebut. Adanya kajian ilmiah dapat menutupi kekurangan terhadap konstruksi bubu tersebut demi mencapai keberhasilan dalam meningkatkan hasil tangkapan yang maksimal (Miswar 2015). Hasil tangkapan yang maksimal akan mempengaruhi produktivitas pada suatu kegiatan operasi penangkapan. Produktivitas hasil tangkapan yang besar merupakan salah satu keberhasilan dalam kegiatan operasi penangkapan, dimana nilai produktivitas akan diperhitungkan untuk mengetahui kerugian dan keuntungan kegiatan operasi penangkapan.

Selain dimensi ukuran bubu, salah satu yang dapat memberikan peningkatan hasil tangkapan, juga beberapa faktor lainnya seperti bahan dan material bubu (Komarudin 2012), menentukan cara peletakan umpan pada bubu (Miller 1990), penggunaan bentuk dan ukuran celah pelolosan (escape gap) (Irawaty 2002, Boutson et al. 2009, Fitri et al. 2017), penggunaan beberapa jenis umpan potensial (Zulkarnain 2012, Purwanto et al. 2013), menentukan posisi mulut bubu (Thomas 1973, Zulkarnain 2012), menentukan jumlah mulut bubu dan lama perendaman (soaking time) bubu di dalam perairan (Anung dan Barus 2000). Terkait dengan mulut bubu sebagai pintu masuknya (entrance) organisme dalam jebakan bubu, ditegaskan kembali bahwa mulut bubu memiliki peran penting pada konstruksi bubu (Miller 1990).

Penelitian mengenai "Penggunaan Dua Pintu pada Konstruksi Mulut Bubu Lipat Modifikasi” merupakan penelitian tentang konstruksi bubu modifikasi dua pintu dibandingkan dengan bubu lipat dua pintu nelayan di wilayah pantai utara jawa dan belum pernah dilakukan sebelumnya. Penelitian ini dilakukan untuk meningkatkan nilai produktivitas hasil tangkapan. Bagian-bagian yang harus diperbaiki adalah jumlah mulut atau pintu bubu. Penambahan jumlah pintu masuk pada sisi samping akan memberikan peluang ikan yang masuk dan terperangkap lebih besar (Hatapayo 2004) dan dapat mengefektifkan kegiatan pada saat penangkapan, sehingga desain dan konstruksi bubu modifikasi dapat menjadi acuan pengembangan bubu lipat dan sebagai alat tangkap alternatif untuk meningkatkan nilai produktivitas hasil tangkapan. Menurut Mizwar (2015) informasi tentang hasil kajian bubu lipat untuk menangkap masih tergolong sedikit, sedangkan informasi tersebut dapat membantu memberikan solusi bagi nelayan untuk meningkatkan hasil tangkapan. Adanya penelitian ini dapat memberikan manfaat berupa informasi kajian tentang pengembangan bubu lipat dengan memodifikasinya sehingga nelayan dapat meningkatkan peluang tangkapannya dengan mengacu konstruksi bubu hasil penelitian. Penelitian ini bertujuan untuk melakukan uji coba penangkapan rajungan dengan bubu lipat modifikasi dua pintu, menentukan komposisi, membandingkan dan menghitung produktivitas bubu lipat modifikasi dengan kontrol.

\section{METODE PENELITIAN}

Penelitian pendahuluan dengan merancang bangun bubu modifikasi dilakukan di Laboratorium TPI, IPB University pada bulan Oktober 2017 hingga Desember 2017. Kemudian pengambilan data melalui experimental fishing sebanyak 20 trip dilakukan pada bulan Desember 2018-Februari 2019 di Dusun Jrakah, Pemalang, Provinsi Jawa Tengah. Kedalaman perairan selama trip penelitian adalah 7$30 \mathrm{~m}$. (Gambar 1). 


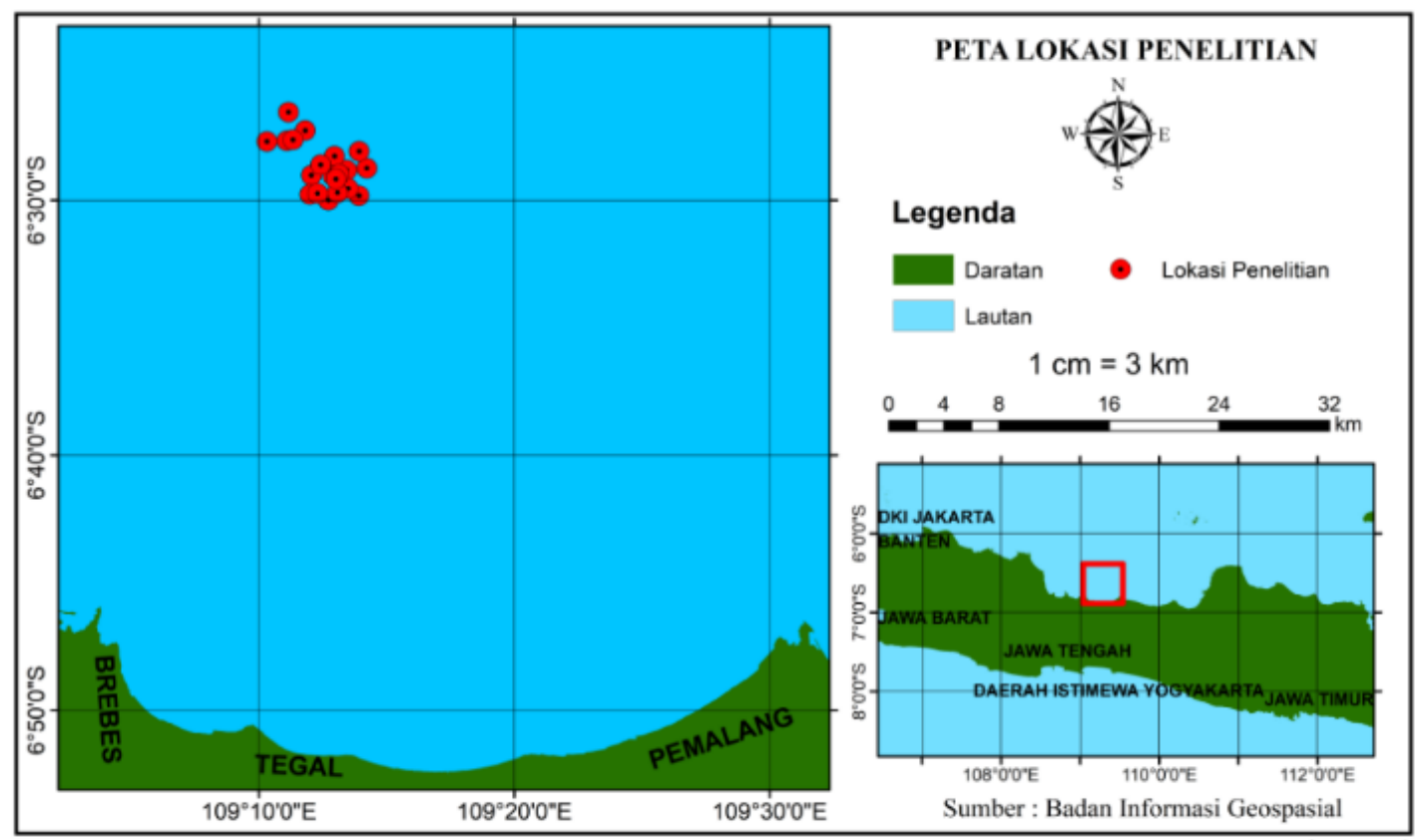

Gambar 1 Perairan Pemalang Sebagai Lokasi Penelitian

Beberapa perangkat dan peralatan digunakan dalam penelitian ini, yaitu komputer yang terhubung dengan jaringan internet yang digunakan untuk mendapatkan informasi jurnal sebagai referensi konstruksi desain bubu, alat tulis, besi galvanis, benang, jaring PE, coban plastik dan tali jaring, kamera digital untuk dokumentasi proses setting, hauling dan hasil tangkapan. Sedangkan peralatan dan bahan yang digunakan pada skala penelitian antara lain perahu untuk 20 trip, unit alat tangkap bubu sistem longline, umpan cacing tanah (Lumbricus rubellus) untuk bubu lipat penelitian, umpan petek untuk bubu lipat nelayan (kontrol), timbangan, termometer, kantong plastik bening, spidol permanen. Penggunaan umpan berupa cacing tanah pada hasil penelitian menunjukkan bahwa cacing tanah dapat dijadikan sebagai umpan altenatif dalam penangkapan, sekaligus memberikan informasi kepada nelayan bubu lipat (Zulkarnain 2012).

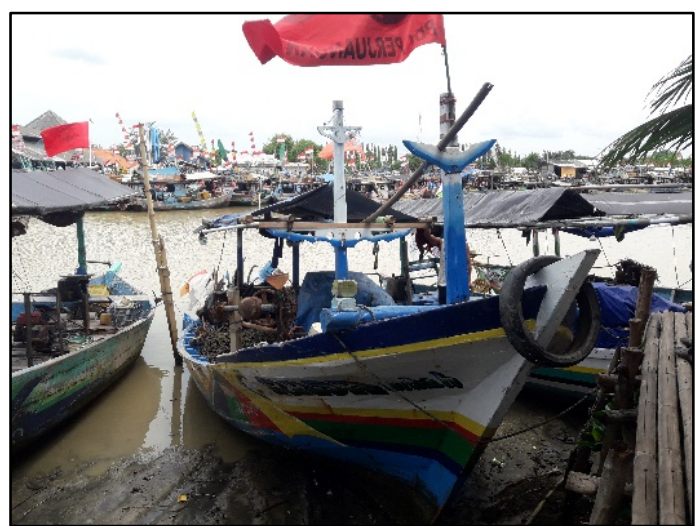

A

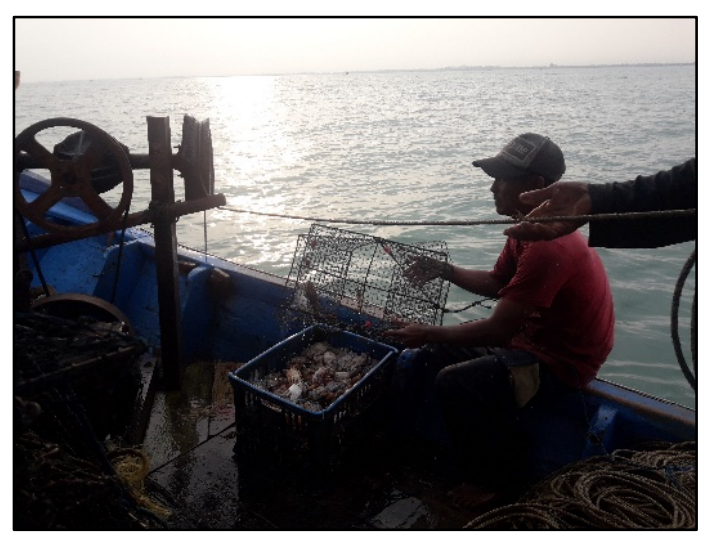

B

Gambar 2 Perahu Penelitian (A) dan Kegiatan Setting Alat Tangkap Bubu (B)

Metode deskriptif digunakan untuk menjelaskan terkait dengan pembuatan bubu lipat penelitian. Metode ini digunakan untuk memberikan suatu gambaran dari alat tangkap terdahulu untuk dijadikan alat tangkap penelitian. Bubu lipat penelitian dapat dilihat pada Gambar 3 dan Gambar 4, dan spesifikasi bubu lipat modifikasi pada Tabel 1 . 

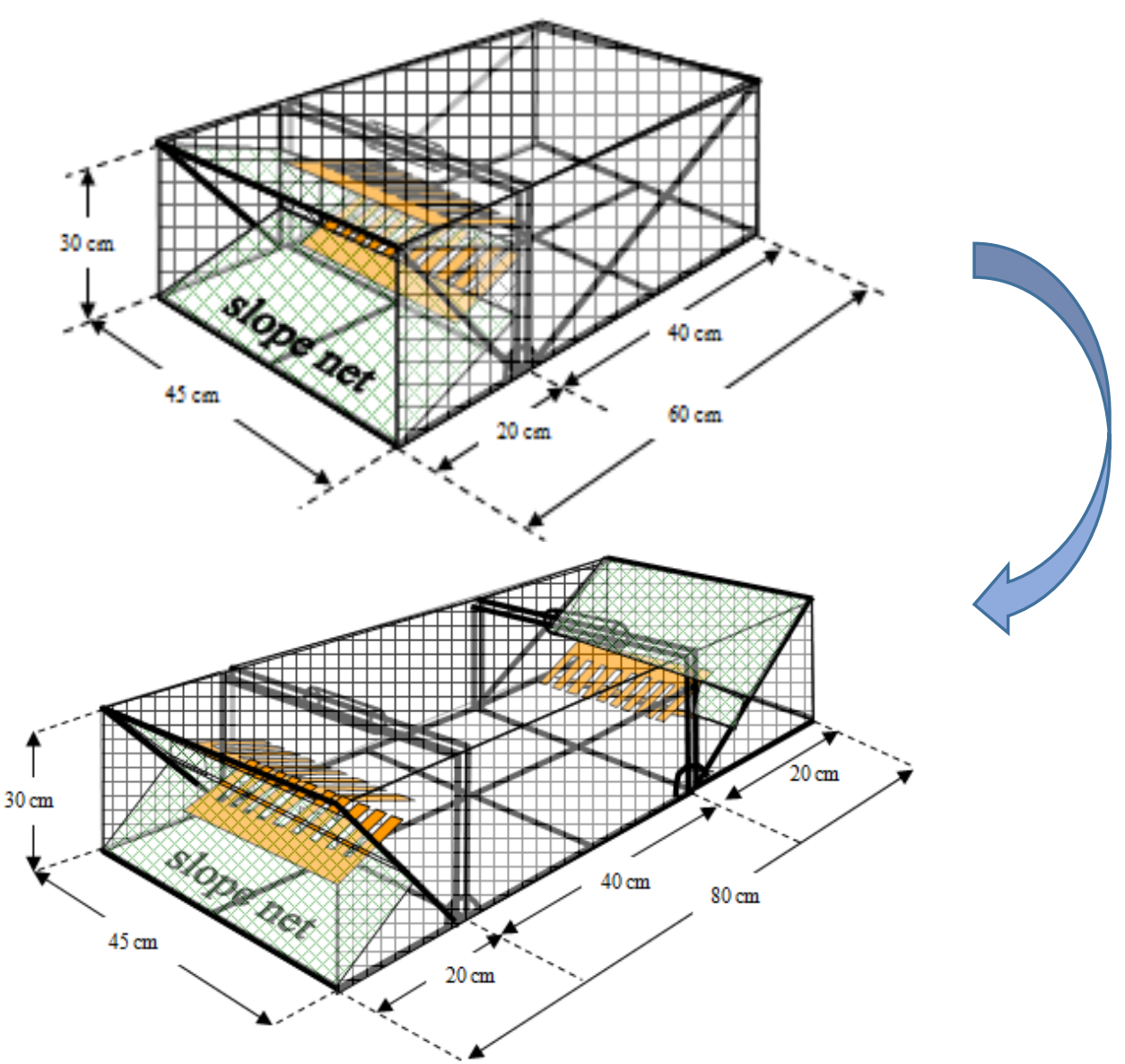

Gambar 3 Bubu Lipat Modifikasi Dua Pintu

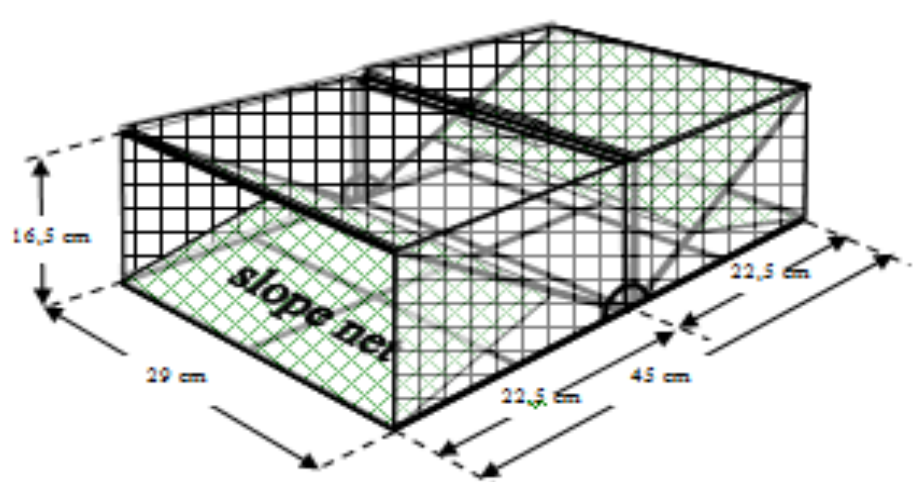

Gambar 4 Bubu Lipat Kontrol Milik Nelayan

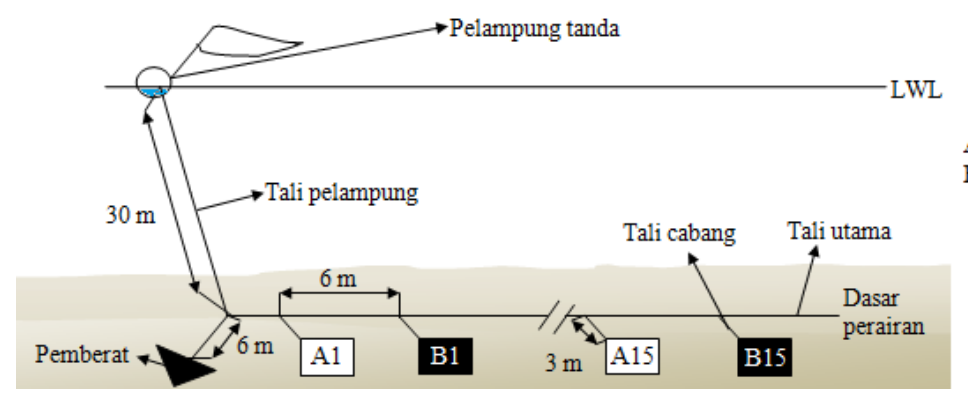
$A=$ Bubu lipat modifikasi dua pintu
$B=$ Bubu lipat (kontrol)

Gambar 5 Metode Pengoperasian Bubu Lipat dengan Sistem Longline 
Tabel 1 Spesifikasi Bubu Lipat Modifikasi

\begin{tabular}{ll}
\hline Bagian Konstruksi & Spesifikasi \\
\hline Bentuk & Box type \\
Dimensi $(\mathrm{cm})$ & $80 \times 55 \times 30$ \\
Pintu masuk & 2 buah \\
Jenis modifikasi & - Ukuran bubu $(\mathrm{cm})$ lebih panjang dan lebar dibandingkan bubu lipat \\
& $\quad$ kontrol $(45 \times 29 \times 16,5)$ \\
& - Slope net $\left(\right.$ atas dan bawah) sama yaitu $22,5^{\circ}$ \\
& - Terdapat pintu jebakan bentuk kisi-kisi bahan fiber plastik \\
& - Sumbu lipatan bubu terletak $20 \mathrm{~cm}$ pada kedua mulut bubu \\
Frame & Besi galvanis, diameter 6 mm \\
Cover net & Polyethylene mesh size 1.5 inch, $210 \mathrm{D} / 18$. \\
\hline
\end{tabular}

Metode experimental fishing atau uji coba lapang sebanyak 20 trip dengan menggunakan metode operasi penangkapan sistem longline. Spesifikasi alat tangkap bubu penelitian ini terdiri dari pelampung tanda (floating buoy) 6 unit, tali pelampung (floating line) 6 unit, pemberat (sinker) 2 unit, tali pemberat (sinker line) 2 set, tali utama (main line) 1 set, jumlah bubu lipat modifikasi dua pintu 15 unit, dan bubu lipat kontrol milik nelayan sebanyak 15 unit.

Komposisi hasil tangkapan pada setiap bubu dianalisis dengan menggunakan data hasil uji coba pada skala lapang. Data yang dilihat berupa berat $(\mathrm{kg})$, jumlah (ekor) dan panjang hasil tangkapan. Kemudian data tersebut dianalisis dengan melihat nilai prosentase dan jumlah total hasil tangkapan pada masing-masing bubu. Hasil tangkapan pada setiap bubu lipat kemudian dapat dianalisis panjang biota layak tangkap dengan cara mengelompokkan hasil tangkapan dalam selang kelas panjang karapas maupun panjang total ikan $(\mathrm{cm})$ yang dihitung menggunakan rumus distribusi frekuensi menurut Walpole (1995), yaitu : $K=1+3,32 \log n$, dengan $K=$ jumlah kelas dan $n=$ jumlah data. Lebar kelas (i) $=[1 / \mathrm{K}] \mathrm{x}$ (nilai terbesar-nilai terkecil).

Data yang terkait mengenai hasil tangkapan ditabulasikan untuk dianalisis uji normalitas. Uji normalitas digunakan untuk mengetahui apakah data berdistribusi normal atau tidak dan digunakan Kolmogorov-Smirnoff dengan menggunakan program IBM SPSS statistics 25. Menurut Santoso (2001) dalam Saputra (2017), bahwa data dapat dikatakan berdistribusi normal apabila nilai Sig $>0,05$ dan sebaliknya dengan nilai Sig $<0,05$ (data tidak normal). Selanjutnya pengolahan data dilakukan dengan menggunakan uji lanjut berupa uji T. Uji T dilakukan apabila data menyebar normal. Uji T dilakukan untuk mengetahui pengaruh dari kedua sampel terhadap jumlah hasil tangkapan dengan menggunakan program IBM SPSS statistics $25(\alpha=0,05)$. Dasar pengambilan keputusan: jika nilai Sig 2-Tailed $>0,05$, maka H0 ditolak, dan jika nilai Sig 2-Tailed $<0,05$, maka H1 diterima. Dasar pengambilan keputusan uji wilcoxon sebagai berikut: jika nilai $A s y m p$. Sig (2-Tailed) lebih kecil dari <0,05, maka H0 diterima. Sebaliknya, jika nilai Asymp. Sig (2-Tailed) lebih kecil dari >0,05, maka H0 ditolak, H1 diterima.

Produktivitas bubu lipat penelitian dianalisis dengan menggunakan rumus produktivitas. Rumus produktivitas bubu sebagai berikut: produktivitas bubu $=R_{R}+R_{L E P}$, dengan $\mathrm{R}_{\mathrm{R}}=$ rataan hasil tangkapan rajungan alat tangkap bubu lipat dengan menggunakan persamaan: [1/(total trip $\mathrm{x}$ total bubu)] x Total rajungan. RLEP = rataan hasil tangkapan lainnya bernilai ekonomis penting pada alat tangkap bubu lipat penelitian dengan menggunakan persamaan : [1/(total trip x total bubu) $]$ x Total HT lainnya ekonomis penting.

\section{HASIL DAN PEMBAHASAN}

Komposisi berat $(\mathrm{kg})$ keseluruhan dan bernilai ekonomis selama 20 trip tercantum pada Tabel 2 dan Tabel 3. Komposisi berat (kg) keseluruhan bubu lipat kontrol berjumlah 9 jenis. Sedangkan, komposisi berat (kg) keseluruhan dari bubu lipat modifikasi dua pintu adalah 11 jenis. Komposisi berat 
(kg) keseluruhan yang bernilai ekonomis dari bubu lipat kontrol berjumlah 4 jenis. Sedangkan, komposisi berat $(\mathrm{kg})$ bernilai ekonomis pada bubu lipat modifikasi dua pintu berjumlah 6 jenis. Hasil tangkapan tersebut merupakan organisme yang hidup atau yang berada di dasar perairan (demersal species). Hal ini karena bubu merupakan alat tangkap yang pengoperasiannya statis di dasar perairan dengan tangkapan spesies demersal (Subani dan Barus 1989).

Tabel 2 Komposisi Berat (kg) Keseluruhan

\begin{tabular}{|c|c|c|c|c|c|c|c|}
\hline \multirow[t]{2}{*}{$\begin{array}{l}\mathrm{N} \\
\mathrm{o}\end{array}$} & \multirow[t]{2}{*}{$\begin{array}{c}\text { Hasil } \\
\text { Tangkapan }\end{array}$} & \multirow[t]{2}{*}{ Nama Inggris } & \multirow[t]{2}{*}{ Nama Ilmiah } & \multicolumn{2}{|c|}{$\begin{array}{l}\text { Bubu Lipat } \\
\text { Kontrol }\end{array}$} & \multicolumn{2}{|c|}{$\begin{array}{c}\text { Bubu Lipat } \\
\text { Modifikasi Dua } \\
\text { Pintu }\end{array}$} \\
\hline & & & & $(\mathrm{Kg})$ & (\%) & $(\mathrm{Kg})$ & $(\%)$ \\
\hline 1 & Rajungan & $\begin{array}{l}\text { Swimming } \\
\text { Crab }\end{array}$ & Portunus sp & 29,14 & 61,42 & 25,63 & 46,69 \\
\hline 2 & Kepiting & Mud crab & Scylla sp & 9,09 & 19,16 & 6,81 & 12,41 \\
\hline 3 & $\begin{array}{l}\text { Udang } \\
\text { Ronggeng }\end{array}$ & Squilla mantis & $\begin{array}{l}\text { Harpiosquilla } \\
\text { raphidea }\end{array}$ & 3,63 & 7,65 & 3,96 & 7,21 \\
\hline 4 & Kakap putih & Snapper fish & Lates calcalifer & 0,00 & 0,00 & 10,12 & 18,44 \\
\hline 5 & Baronang & Rabbitfishes & Siganidae & 0,00 & 0,00 & 3,32 & 6,05 \\
\hline 6 & $\begin{array}{l}\text { Kerong- } \\
\text { kerong }\end{array}$ & Terapon & Terapon Theraps & 0,04 & 0,08 & 1,19 & 2,16 \\
\hline 7 & Gurita & Octopus & Octopoda & 0,10 & 0,21 & 0,25 & 0,46 \\
\hline 8 & Teripang & Sea cucumber & $\begin{array}{l}\text { Paracaudina } \\
\text { australis }\end{array}$ & 4,19 & 8,83 & 2,60 & 4,74 \\
\hline 9 & Bintang Laut & Starfish & Asteroidea & 0,43 & 0,91 & 0,31 & 0,56 \\
\hline 10 & Keong Laut & Sea snail & Gibbula divaricata & 0,80 & 1,69 & 0,63 & 1,16 \\
\hline 11 & Siput Karang & $\begin{array}{l}\text { Hexaplex } \\
\text { trunculus }\end{array}$ & Bolinus brandaris & 0,02 & 0,04 & 0,08 & 0,15 \\
\hline & Total & & & 47,44 & & 54,89 & \\
\hline
\end{tabular}

Tabel 3 Komposisi Berat (kg) Keseluruhan yang Bernilai Ekonomis

\begin{tabular}{|c|c|c|c|c|c|c|c|}
\hline \multirow[t]{2}{*}{$\begin{array}{l}\mathrm{N} \\
\mathrm{o}\end{array}$} & \multirow[t]{2}{*}{$\begin{array}{c}\text { Hasil } \\
\text { Tangkapan }\end{array}$} & \multirow[t]{2}{*}{ Nama Inggris } & \multirow[t]{2}{*}{ Nama Ilmiah } & \multicolumn{2}{|c|}{$\begin{array}{l}\text { Bubu Lipat } \\
\text { Kontrol }\end{array}$} & \multicolumn{2}{|c|}{$\begin{array}{c}\text { Bubu Lipat } \\
\text { Modifikasi Dua } \\
\text { Pintu }\end{array}$} \\
\hline & & & & $(\mathrm{Kg})$ & $(\%)$ & $(\mathrm{Kg})$ & $(\%)$ \\
\hline \multirow[t]{2}{*}{1} & Rajungan & Swimming Crab & Portunus sp & 29,14 & 61,42 & 25,63 & 46,69 \\
\hline & Subtotal & & & 29,14 & & 25,63 & \\
\hline 2 & $\begin{array}{l}\text { Udang } \\
\text { Ronggeng }\end{array}$ & Squilla mantis & $\begin{array}{l}\text { Harpiosquilla } \\
\text { sp }\end{array}$ & 3,63 & 3,63 & 3,96 & 7,21 \\
\hline 3 & Kakap & Snapper fish & Lates calcalifer & 0,00 & 0,00 & 10,12 & 18,44 \\
\hline 4 & Baronang & Rabbitfishes & Siganidae & 0,00 & 0,00 & 3,32 & 6,05 \\
\hline 5 & Kerong-kerong & Terapon & $\begin{array}{l}\text { Terapon } \\
\text { Theraps }\end{array}$ & 0,04 & 0,04 & 1,19 & 2,16 \\
\hline \multirow[t]{3}{*}{6} & Gurita & Octopus & Octopoda & 0,10 & 0,10 & 0,25 & 0,46 \\
\hline & Subtotal & & & 3,77 & & 18,89 & \\
\hline & Total & & & 32,91 & & 44,52 & \\
\hline
\end{tabular}

Komposisi jumlah (ekor) keseluruhan dan komposisi jumlah (ekor) keseluruhan yang bernilai ekonomis selama 20 trip dapat dilihat pada Tabel 4 dan Tabel 5. Sedangkan, komposisi berat $(\mathrm{kg})$ keseluruhan yang bernilai ekonomis dan komposisi jumlah (ekor) keseluruhan yang bernilai ekonomis 
dapat dilihat pada Gambar 6 dan Gambar 7. Komposisi berat (kg) rajungan dan komposisi jumlah (ekor) keseluruhan rajungan dapat dilihat pada Gambar 8 dan Gambar 9.

Tabel 4 Komposisi Jumlah (ekor) Keseluruhan

\begin{tabular}{|c|c|c|c|c|c|c|c|}
\hline \multirow[t]{2}{*}{ No } & \multirow[t]{2}{*}{ Hasil Tangkapan } & \multirow[t]{2}{*}{ Nama Inggris } & \multirow[t]{2}{*}{ Nama Ilmiah } & \multicolumn{2}{|c|}{$\begin{array}{c}\text { Bubu Lipat } \\
\text { Kontrol }\end{array}$} & \multicolumn{2}{|c|}{$\begin{array}{c}\text { Bubu Lipat } \\
\text { Modifikasi Dua } \\
\text { Pintu }\end{array}$} \\
\hline & & & & (Ekor) & $(\%)$ & (Ekor) & $(\%)$ \\
\hline 1 & Rajungan & $\begin{array}{l}\text { Swimming } \\
\text { Crab }\end{array}$ & Portunus sp & 250 & 24,56 & 223 & 19,68 \\
\hline 2 & Kepiting & Mud $c r a b$ & Scylla sp & 282 & 27,70 & 261 & 23,04 \\
\hline 3 & Udang Ronggeng & Squilla mantis & Harpiosquilla sp & 75 & 7,37 & 99 & 8,74 \\
\hline 4 & Kakap & Snapper fish & Lates calcalifer & 0 & 0,00 & 48 & 4,24 \\
\hline 5 & Baronang & Rabbitfishes & Siganidae & 0 & 0,00 & 66 & 5,83 \\
\hline 6 & Kerong-kerong & Terapon & Terapon theraps & 1 & 0,10 & 52 & 4,59 \\
\hline 7 & Gurita & Octopus & Octopoda & 3 & 0,29 & 5 & 0,44 \\
\hline 8 & Teripang & Sea cucumber & Paracaudina sp & 178 & 17,49 & 160 & 14,12 \\
\hline 9 & Bintang Laut & Starfish & Asteroidea & 36 & 3,54 & 30 & 2,65 \\
\hline 10 & Keong Laut & Sea snail & Gibbula sp & 192 & 18,86 & 185 & 16,33 \\
\hline \multirow[t]{2}{*}{11} & Siput Karang & $\begin{array}{l}\text { Hexaplex } \\
\text { trunculus }\end{array}$ & Bolinus sp & 1 & 0,10 & 4 & 0,35 \\
\hline & Total & & & 1018 & & 1133 & \\
\hline
\end{tabular}

Tabel 5 Komposisi Jumlah (ekor) Keseluruhan yang Bernilai Ekonomis

\begin{tabular}{|c|c|c|c|c|c|c|c|}
\hline \multirow[t]{2}{*}{ No } & \multirow[t]{2}{*}{ Hasil Tangkapan } & \multirow[t]{2}{*}{ Nama Inggris } & \multirow[t]{2}{*}{ Nama Ilmiah } & \multicolumn{2}{|c|}{$\begin{array}{c}\text { Bubu Lipat } \\
\text { Kontrol }\end{array}$} & \multicolumn{2}{|c|}{$\begin{array}{c}\text { Bubu Lipat } \\
\text { Modifikasi Dua } \\
\text { Pintu } \\
\end{array}$} \\
\hline & & & & (Ekor) & $(\%)$ & (Ekor) & $(\%)$ \\
\hline \multirow[t]{2}{*}{1} & Rajungan & $\begin{array}{l}\text { Swimming } \\
\text { Crab }\end{array}$ & Portunus sp & 250 & 24,56 & 223 & 19,68 \\
\hline & Subtotal & & & 250 & & 223 & \\
\hline 2 & Udang Ronggeng & Squilla mantis & Harpiosquilla sp & 75 & 7,37 & 99 & 8,74 \\
\hline 3 & Kakap putih & Snapper fish & Lates calcalifer & 0 & 0,00 & 48 & 4,24 \\
\hline 4 & Baronang & Rabbitfishes & Siganidae & 0 & 0,00 & 66 & 5,83 \\
\hline 5 & Kerong-kerong & Terapon & Terapon theraps & 1 & 0,10 & 52 & 4,59 \\
\hline 6 & Gurita & Octopus & Octopoda & 3 & 0,29 & 5 & 0,44 \\
\hline \multicolumn{2}{|r|}{ Subtotal } & & & \multicolumn{2}{|l|}{79} & \multicolumn{2}{|l|}{270} \\
\hline \multicolumn{3}{|c|}{ Total } & & 329 & & 493 & \\
\hline
\end{tabular}




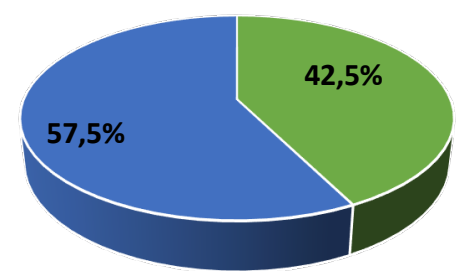

- Bubu lipat kontrol

- Bubu lipat modifikasi dua pintu

Gambar 6 Komposisi Berat (kg) Keseluruhan yang Bernilai Ekonomis

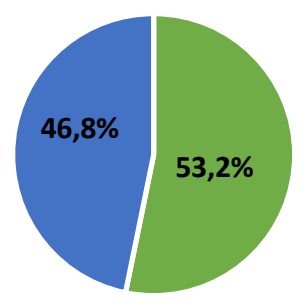

- Bubu lipat kontrol

- Bubu lipat modifikasi dua pintu

Gambar 8 Komposisi Berat (kg) Keseluruhan Rajungan

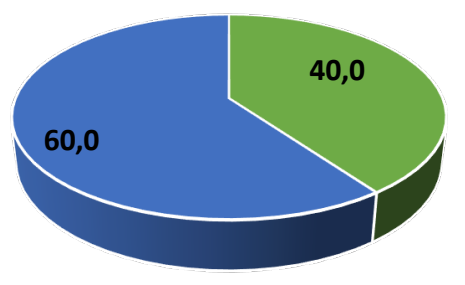

- Bubu lipat kontrol

- Bubu lipat modifikasi dua pintu

Gambar 7 Komposisi Jumlah (ekor) yang Bernilai Ekonomis

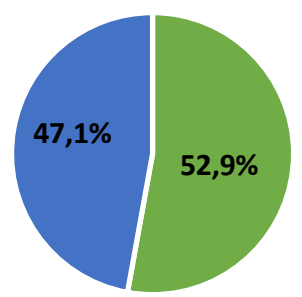

- Bubu lipat kontrol

- Bubu lipat modifikasi dua pintu

Gambar 9 Komposisi Jumlah (ekor)

Keseluruhan Rajungan

Sebaran panjang karapas rajungan yang tertangkap dapat dilihat pada Gambar 10. Menurut PERMEN NOMOR 1/PERMEN-KP/2015 tentang Penangkapan lobster (Panulirus sp.), kepiting (Scylla sp.), dan rajungan (Portunus pelagicus) pada pasal 3 ayat Ia mengatakan penangkapan rajungan dapat dilakukan dengan ukuran panjang karapas $>10 \mathrm{~cm}$. Rajungan yang tertangkap dengan kategori layak tangkap pada bubu lipat kontrol adalah $80 \%$. Sedangkan, rajungan yang tertangkap dengan kategori layak tangkap pada bubu lipat modifikasi dua pintu adalah $68 \%$.

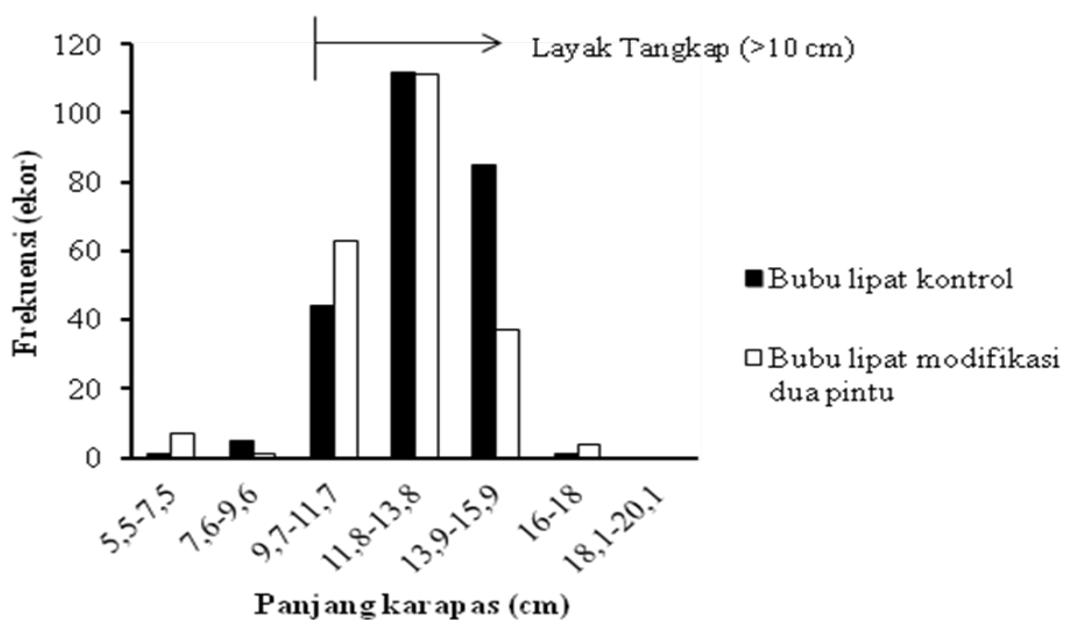

Gambar 10 Sebaran Panjang Karapas Rajungan yang Tertangkap 
Komposisi berat $(\mathrm{kg})$ keseluruhan rajungan pada bubu lipat modifikasi tidak menyebar normal, sedangkan menyebar normal pada komposisi jumlah (ekor) keseluruhan rajungan. Uji Wilcoxon $(>0,052)$ dan uji $\mathrm{T}(<0,107)$ yang menunjukkan bahwa tidak ada perbedaan yang signifikan antara bubu lipat kontrol dengan bubu lipat modifikasi dua pintu pada selang kepercayaan 95\%. Rata-rata berat $(\mathrm{kg})$ \pm SE rajungan dapat dilihat pada Gambar 11.

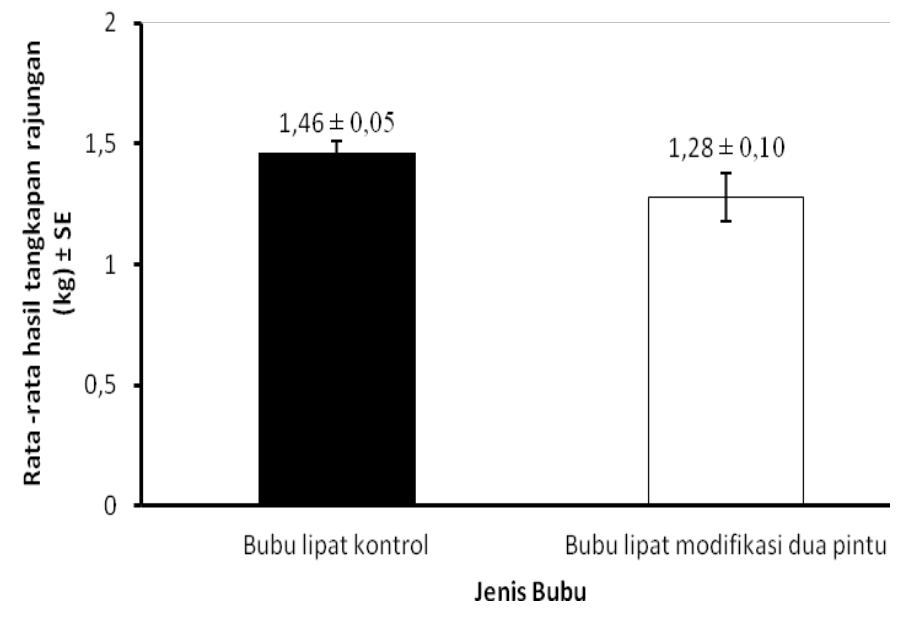

Gambar 11 Rata-rata Berat $(\mathrm{kg}) \pm$ SE Rajungan dari Kedua Perlakuan

Data keseluruhan berat $(\mathrm{kg})$ dan jumlah (ekor) yang bernilai ekonomis menyebar normal dan Nilai signifikansi 2-Tailed pada masing-masing data 0,001 dan 0,014. Hal ini memberikan makna bahwa bubu lipat modifikasi dua pintu berpengaruh terhadap komposisi berat $(\mathrm{kg})$ keseluruhan yang bernilai ekonomis pada selang kepercayaan $95 \%$. Rata-rata berat $(\mathrm{kg}) \pm \mathrm{SE}$ yang bernilai ekonomis tercantum pada Gambar 12.

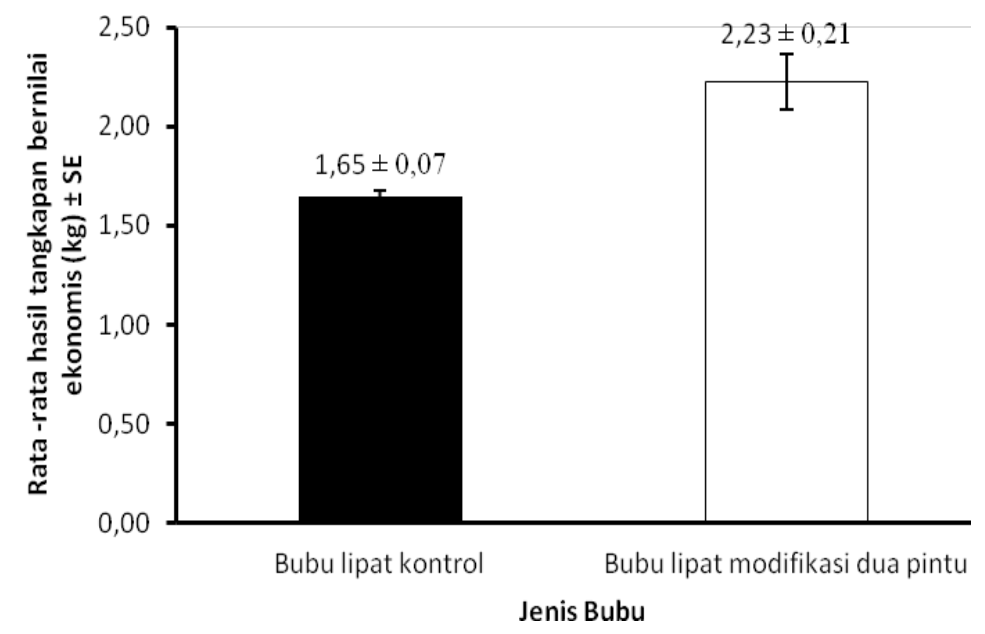

Gambar 12 Rata-rata Berat $(\mathrm{kg}) \pm$ SE yang Bernilai Ekonomis dari Kedua Perlakuan

Pada Tabel 6 ditunjukkan nilai produktivitas bubu lipat modifikasi dua pintu lebih besar dibandingkan bubu lipat kontrol.

Tangkapan jenis rajungan sebanyak $0,096 \mathrm{~kg} / \mathrm{bubu}$ dan tangkapan lainnya yang bernilai ekonomis sebesar 0,012 kg/bubu/trip sebagai nilai produktifitas bubu lipat kontrol. Sedangkan tangkapan jenis rajungan sebanyak $0,083 \mathrm{~kg} / \mathrm{bubu} /$ trip dan tangkapan lainnya yang bernilai ekonomis sebanyak $0,062 \mathrm{~kg} / \mathrm{bubu} /$ trip sebagai nilai produktifitas bubu lipat modifikasi dua pintu. 
Tabel 6 Produktifitas Bubu Lipat

\begin{tabular}{llll}
\hline Perlakuan & Rajungan & LEP & Total \\
\hline Bubu Kontrol & 0,096 & 0,012 & 0,108 \\
Bubu Modifikasi & 0,083 & 0,062 & 0,145 \\
\hline
\end{tabular}

Menurut Groneveld (2000) bubu merupakan jenis alat tangkap yang bersifat selektif dan berdampak kecil bagi biota di dasar perairan (Eno et al. 2001) dimana hasil tangkapan (under size) dapat dikembalikan ke perairan tanpa melukainya. Menurut Miller (1990) bubu biasa digunakan untuk menangkap jenis crustasea dan target tangkapan lainnya seperti mollusca, ikan bersirip, dan gastropoda. Bubu lipat digunakan untuk menangkap rajungan di Sulawesi Selatan, Lampung, perairan pantai utara Laut Jawa, Madura, dan Maluku (Zulkarnain 2012) dan menangkap gurita di Jepang (Archdale et al. 2003). Menurut Martasuganda (2003) penentuan daerah penangkapan untuk perikanan bubu tidak seperti halnya menentukan daerah penangkapan untuk ikan tuna dan ikan pelagis pada umumnya yang harus memperhitungkan faktor oseanografi, kelimpahan plankton dan faktor lainnya, hal terpenting dalam menentukan daerah penangkapan adalah diketahuinya keberadaan ikan dasar, kepiting atau udang sebelum pengoperasian dilakukan dengan mennggunakan alat pendeteksi ikan (fish finder).

Bubu lipat modifikasi dua pintu dilengkapi dengan pintu jebakan berbentuk kisi-kisi. Penambahan pintu jebakan berbentuk kisi merupakan desain yang dapat menambah peluang masuk dan mudah masuknya biota ke dalam bubu dan tidak mudah untuk meloloskan diri (Zulkarnain 2012) dan konstruksi yang pertama kali dibuat oleh (Zulkarnain 2012). Hal ini dibuktikan dengan hasil wawancara dengan nelayan di Dusun Jrakah, Kabupaten Pemalang bahwa bubu lipat modifikasi dua pintu dengan menggunakan kisi baru pertama kali dioperasikan di pesisir pantai laut Jawa khususnya di Dusun Jrakah, Kabupaten Pemalang.

Perbedaan spesifikasi terletak pada dimensi ukuran bubu dan mulut bubu. Dimensi ukuran bubu lipat modifikasi dua pintu lebih besar enam kali dari ukuran volume bubu lipat nelayan. Adanya perbedaan ukuran kedua bubu tersebut disebabkan karena adanya penambahan konstruksi mulut bubu lipat modifikasi pada bagian samping. Menurut Anwar (2001) letak mulut bubu terbaik adalah letak mulut di bagian samping. Hal ini terjadi karena letak mulut bubu di samping lebih mudah ditemukan karena jaraknya yang dekat dengan dasar perairan dan adanya dua mulut bubu sebagai pintu masuk biota.

Bentuk persegi panjang ( box type) dari mulut bubu lipat modifikasi dilengkapi dengan kisi-kisi fibre plastic. Bentuk mulut persegi panjang (box type) memiliki peluang biota untuk masuk lebih besar dibandingkan dengan bentuk mulut bubu berbentuk ellips atau slit type karena pada bubu lipat nelayan memiliki ukuran bukaan mulut yang lebih sempit $(8 \mathrm{~cm})$ dibandingkan dengan bukaan mulut bubu lipat modifikasi dua pintu yang relatif lebih besar $(14 \mathrm{~cm})$. Menurut Martasuganda (2003) bentuk bubu yang bervariasi tersebut disesuaikan dengan ikan yang akan dijadikan target tangkapan. Meskipun yang dijadikan target sama, terkadang bentuk bubu yang dipakai bisa juga berbeda, sehingga jumlah tangkapan baik dalam jumlah maupun rata-rata yang didapat juga berbeda. Kemiringan slope yang sama pada bubu lipat modifikasi yakni $45^{\circ}$. Menurut Mizwar (2015) biota lebih mudah masuk pada slope kemiringan $45^{\circ}$. Selain itu, adanya persamaan kemiringan slope $\alpha$ dan $\beta$ pada bubu memberikan bubu lipat modifikasi dua pintu memiliki keistimewaan dibandingkan bubu lipat nelayan dengan slope kemiringan yang berbeda yakni slope kemiringan bawah $\left(\alpha=35^{\circ}\right)$ dan $\left(\beta=55^{\circ}\right)$. Keistimewaan tersebut yaitu tidak mudah mengubah konstruksi slope (terbalik) apabila terjadi ketidakberhasilan dalam setting maupun adanya kondisi alam.

Hasil experimental fishing mendapatkan 11 jenis antara lain kerong-kerong (Terapon theraps), rajungan (Portunus pelagicus), baronang (Siganus sp), kepiting (Scylla sp.), udang ronggeng (Harpiosquilla raphidea), kakap putih (Lates calcalifer), bintang laut (Asteroidea sp), gurita (Octopus sp), siput karang (Bolinus brandaris), keong laut (Gibbula sp), dan teripang (Paracaudina australis) dan 
6 dari 11 jenis merupakan jenis yang bernilai ekonomis antara lain rajungan (Portunus pelagicus), udang ronggeng (Harpiosquilla raphidea), kakap putih (Lates calcalifer), baronang (Siganus sp), kerongkerong (Terapon theraps), gurita (Octopus sp). Rajungan adalah jenis yang banyak tertangkap pada bubu lipat penelitian. Namun, dilihat dari berat $(\mathrm{kg})$ rajungan yang tertangkap pada bubu lipat kontrol sebanyak 29,14 kg dengan rata-rata berat $(\mathrm{kg})$ rajungan $\pm \mathrm{SE}$ sebesar 1,46 $\pm 0,05$ sementara rajungan sebanyak $25,63 \mathrm{~kg}$ dan rata-rata berat $(\mathrm{kg}) \pm \mathrm{SE}$ sebesar $1,28 \pm 0,10$ pada bubu lipat modifikasi dua pintu. Selain itu, hasil tangkapan lainnya yang bernilai ekonomis pada bubu lipat modifikasi dua pintu seperti jenis ikan yang tertangkap lebih banyak 44,52 kg dengan rata-rata total hasil tangkapan lainnya yang bernilai ekonomis \pm SE sebesar 2,23 $\pm 0,21$ dibandingkan pada bubu lipat nelayan $32.91 \mathrm{~kg}$ dengan ratarata total hasil tangkapan lainnya yang bernilai ekonomis \pm SE sebesar $1.65 \pm 0.07$. Artinya, penggunaan dua pintu pada konstruksi bubu lipat modifikasi berpengaruh nyata terhadap komposisi hasil tangkapan lainnya yang bernilai ekonomis dan tidak berpengaruh nyata terhadap komposisi hasil tangkapan rajungan.

Diskusi dengan nelayan bubu rajungan, bahwa banyaknya hasil tangkapan yang diperoleh akan sangat tergantung pada kondisi bubu yang dipengaruhi oleh air laut. Semakin sering terendam di air laut maka dianggap bahwa bubu sudah menyatu dengan kondisi dasar perairan. Menurut Anggraini (1991) perbedaan bobot pada masing-masing bubu dapat dipengaruhi oleh beberapa faktor. Faktor yang dapat mempengaruhi yaitu faktor intrinsik dan faktor ekstrinsik. Faktor intrinsik meliputi ukuran, jenis kelamin, tingkat kedewasaan, dan cacat tubuh. Sedangkan faktor ekstrinsik yaitu ketersediaan makanan, suhu lingkungan dan parasit. Namun faktor yang ditemukan dalam uji coba lapang yaitu faktor intrinsik berupa ukuran, dimana biota yang berukuran lebih besar berbanding lurus dengan berat dalam kg. Salah satu faktor yang mempengaruhi keberhasilan suatu usaha penangkapan yaitu faktor produksi, dimana produktivitas bubu dihitung dari hasil tangkapan dengan satuan bobot per upaya penangkapannya untuk selanjutnya dihitung untuk mengetahui tingkat keuntungan, tingkat pendapatan dan tingkat kerugian suatu usaha penangkapan dengan menggunakan bubu lipat. Sehingga dengan adanya kajian ilmiah ini dapat menjadikan bubu lipat modifikasi dua pintu sebagai alat tangkap alternatif secara komersial ditinjau dari nilai produktivitas hasil tangkapannya.

\section{KESIMPULAN DAN SARAN}

Komposisi berat $(\mathrm{kg})$ bubu lipat modifikasi dua pintu lebih banyak $(54,89 \mathrm{~kg})$ dibandingkan dengan bubu lipat nelayan $(47,44 \mathrm{~kg})$. Bubu lipat modifikasi dua pintu tidak berpengaruh nyata terhadap komposisi berat $(\mathrm{kg})$ dan jumlah (ekor) rajungan. Namun, berpengaruh nyata dengan komposisi berat $(\mathrm{kg})$ maupun jumlah (ekor) keseluruhan dan hasil tangkapan bernilai ekonomis. Nilai produktivitas pada bubu lipat modifikasi dua pintu lebih besar $(0,145 \mathrm{~kg} / \mathrm{bubu} / \mathrm{trip})$ dibandingkan dengan bubu lipat kontrol (0,105 kg/bubu/trip).

\section{DAFTAR PUSTAKA}

Anggraini E. 1991. Regenerasi alat gerak, pertahanan bobot tubuh pasca lepas cangkang, dan kajian morfometrik kepiting bakau (Scylla serrata, Forskal) di Rawa Payau Muara Sungai Cikaso, Kabupaten Sukabumi [skripsi]. Bogor (ID): Institut Pertanian Bogor.

Anung A, Barus HR. 2000. Pengaruh jumlah mulut, jenis umpan dan lama perendaman bubu terhadap hasil tangkapan ikan demersal di Selat Sunda. Prosiding Seminar Hasil Penelitian Perikanan 1999/2000. Pusat Penelitian dan Pengembangan Eksplorasi Laut dan Perikanan. Jakarta(ID):133139.

Anwar SN. 2001. Studi pendahuluan letak mulut bubu dan tingkah laku udang karang hijau pasir (Panulirus Homarus) [skripsi]. Bogor (ID): Institut Pertanian Bogor. 
Archdale VM, Anraku K, Yamamoto T, Higashitani N. 2003. Behaviour of the japanese rock crab 'ishigani' Charybdis japonica towards two collabsible baited pots: evaluation of capture effectiveness. Fisheries Science. 69:785-791.

Baskoro MS. 2006. Alat penangkapan ikan berwawasan lingkungan dalam kumpulan pemikiran tentang teknologi perikanan tangkap yang bertanggungjawab. Kenangan Purnabakti Prof. Dr. Ir. Daniel R. Monintja. Departemen Pemanfaatan Sumberdaya Perikanan. Fakultas Perikanan dan Ilmu Kelautan. Bogor (ID): Institut Pertanian Bogor.

Baskoro MS, Effendy A. 2005. Tingkah laku ikan hubungannya dengan metode pengoperasian alat penangkapan ikan. Jurnal PSP. 16(3):171-180.

Boutson A, Mahasawasde C, Mahasawasde S, Tunkijjanukij S, Arimoto T. 2009. Use of Escape Vents to Improve Size and Species Selectivity of Collapsible Pot for Blue Swimming Crab Portunus pelagicus in Thailand. Fisheries Science. 75:25-33.

Eno CN, MacDonald DS, Kiennar JA, Awos SC, Chapman CJ, Clark RA, Bunker FPD, Munro C. 2001. Effect of crustasean traps on benthic fauna. ICES Journal Marine Science. 58:11-20.

Fitri, Aristi DP, Prakosa FE, Faik K. 2017. Analisis celah pelolosan pada bubu kubah terhadap hasil tangkapan rajungan (Portunus pelagicus) di TPI Demaan, Kabupaten Jepara. Fisheries Resources Utilization Management and Technology. 6(4):103-109.

Groneveld JC. 2000. Stock assesment, ecology and economics as criteria for choosing between trap and trawl fisheries for spiny lobster palinurus delagoae. Fisheries research. 48(2):141-155.

Hatapayo R. 2004. Pengaruh penggunaan umpan yang berbeda pada bubu dasar di Perairan Tehoru Kabupaten Maluku Tengah [skripsi]. Makasar (ID): Universitas Muslim Indonesia.

Herisdiana. 2017. Dampak perikanan bubu terhadap ikan target dan fungsi ekosistem di Pulau Harapan, Kepulauan Seribu [skripsi]. Bogor (ID): Institut Pertanian Bogor.

Irawaty R. 2002. Studi tingkah laku pelolosan kerapu macan (Epinephelus fuscoguttatus) pada bubu yang dilengkapi dengan celah pelolosan (escaping gap) [skripsi]. Bogor (ID) : Institut Pertanian Bogor.

Iskandar D, Rachmad C. 2013. Pengaruh posisi umpan terhadap hasil tangkapan bubu lipat. Buletin PSP. 21(1):1-9.

Komarudin D. 2012. Rancang bangun bubu lipat untuk menangkap kepiting bakau (Scylla serrata) [tesis]. Bogor (ID): Institut Pertanian Bogor.

Krouse JS. 1989. Performance and selectivity of trap fisheries for crustaceans. In: Caddy, J.F. (Ed.), Marine Invertebrate Fisheries: Their assessment and management. John Wiley and Sons, New York. 307-325p.

Martasuganda S. 2003. Bubu (Trap). Bogor (ID) : Institut Pertanian Bogor, Fakultas Perikanan dan Ilmu Kelautan.

Mashar A, Yusli W. 2011. Population dynamics of the Indonesian mantis shrimp, Harpiosquilla raphidea (Fabricius 1798) (crustasea: stomatopoda) collected from a mud flat in Kuala Tungkal, Jambi Province, Sumatera Island. Journal of marine sciences. 16(2):111-118.

Miller RJ. 1990. Effectiveness of crab and lobster traps. Journal of fisheries and aquatic science. $47(4): 1228-1251$.

Mizwar E. 2015. Modifikasi bubu lipat untuk pemanfaatan lobster [tesis]. Bogor (ID): Institut Pertanian Bogor. 
[PERMENKP/01/2015] Tentang penangkapan lobster (Panulirus spp.), kepiting (Scylla spp.), dan rajungan (Portunus pelagicus spp.)

Purwanto, Akir A, Arsti DPF, Bambang AW. 2013. Perbedaan umpan terhadap hasil tangkapan udang galah (Macrobracrium idea) alat tangkap bubu bambu (ICIR) di Perairan Rawapening. Fisheries Resources Utilization Management and Technology. 3(2):72-81.

Saputra DO. 2017. Penggunaan umpan wak-wak (Xenosiphon sp.) pada pancing ulur yang dioperasikan siang hari di Kecamatan Manggar Pulau Belitung [skripsi]. Bogor (ID): Institut Pertanian Bogor.

Saputra DO, Zulkarnain, Purwaka F, Izza MA. 2018. Penggunaan umpan wak-wak (Xenosiphon sp.) pada pancing ulur yang dioperasikan siang hari di Kecamatan Manggar Pulau Belitung. Jurnal Akuatik Indonesia. 3(2):110-118.

Subani W, Barus HR. 1989. Alat penangkap ikan dan udang laut di Indonesia. Jurnal Penelitian Perikanan Laut No. 5 Th. 1988/1989. Edisi khusus. Jakarta(ID) : Balai Penelitian Perikanan Laut.

Thomas HJ. 1973. A comparison of some methods used in lobster and crab fishing. Scottish fisheries information pamphlets. 4th Edition. Marine laboratory, Aberdeen. Departement of Agriculture and Fisheries for Scotland.

Zulkarnain, Baskoro MS, Martasuganda S, Monintja DR. 2011. Pengembangan desain bubu lobster yang efektif. Buletin PSP. 16(2):45-47.

Zulkarnain, Baskoro MS, Martasuganda S, Monintja DR. 2011. Efektivitas bubu lipat modifikasi dan penggunaan umpan cacing tanah (Lumbricus rubellus) pada penangkapan spiny lobster (Panulirus spp.) di perairan pesisir timur teluk pelabuhanratu Jawa Barat. Buletin PSP. 16(3):239-252.

Zulkarnain. 2012. Rancang bangun bubu lipat modifikasi dan penggunaan cacing tanah (Lumbricus rubellus) sebagai umpan alternatif untuk penangkapan spiny lobster [disertasi]. Bogor (ID): Institut Pertanian Bogor. 